\title{
REFRACTIONS, ADAPTATIONS, AND SIMPLIFICATIONS OF JOSEPH CONRAD'S HEART OF DARKNESS IN THE POLISH CULTURE IN THE TWENTY-FIRST CENTURY
}

\author{
Agnieszka Adamowicz-Pośpiech \\ University of Silesia
}

\begin{abstract}
The paper aims at a comparative analysis of four Polish retranslations of Heart of Darkness, not to show the differences but to reveal the procedures and techniques by means of which translators, editors, and publishers refract (manipulate) the translated text. It is my contention that particular versions of Heart of Darkness function in diverse ways in Polish culture and each rendition is targeted at a different audience. The retranslations will be analysed using the methodology of the Manipulation School and its development by André Lefevere.
\end{abstract}

Keywords: Heart of Darkness, refraction, simplification, adaptation, retranslation

The paper aims at a comparative analysis of four Polish retranslations of Heart of Darkness, not to show the differences (for translation shifts always occur and different translators render the same text in various ways), but to reveal the procedures and techniques by means of which translators, editors, and publishers refract (manipulate) the translated text. It is my contention that particular versions of Heart of Darkness function in diverse ways in Polish culture and each rendition is targeted at a different audience. In line with Descriptive Translation Studies, the purpose of the analysis is not to evaluate the retranslations ${ }^{1}$ but to highlight the forms of manipulation (refraction, adaptation or simplification) applied to the original.

There are few books that have seven or eight retranslations within two decades. Excluding Shakespeare dramas which are translated anew each time there is a new theatrical production or Alice in Wonderland which presents for the translators a similar challenge as the Himalayas for the alpinists, ${ }^{2}$ the others can be quickly counted. There is also another class of books whose retranslations proliferate due to economic or market reasons since the publishers count on short-term and high returns (in the

\footnotetext{
${ }^{1}$ G. Toury, In Search of a Theory of Translation, Tel Aviv: Porter Institute, 1980.

${ }^{2}$ E. Tabakowska, "Słowo-po-słowie od thumacza" [Word-by-word by the Translator] [in:] L. Carroll, Alicja w Krainie Czarów, transl. E. Tabakowska, Kraków: Bona, 2012, p. 116.
} 
case of well known authors or books that are set as obligatory reading at schools). ${ }^{3}$ Heart of Darkness can be placed in both categories: on the one hand, it is obligatory reading for secondary school pupils and some undergraduate students, on the other, it belongs to the European canon and poses a challenge for each generation of translators who want to modernize the text and make it accessible for contemporary readers. Among the selected for this study four retranslations of Heart of Darkness, there are examples of both approaches: in the first group one can place the renditions by Patrycja Jabońska and the first version of Jędrzej Polak while in the other group we can find the translations by Barbara Koc, Magda Heydel and the corrected version (the second variant) of Polak.

The object of the essay, as has been already stated, is to examine how the selected variants of Heart of Darkness function in the Polish culture of the XXI century; in other words: how they have been promoted, what context they are written into, and what type of paratexts accompany them. The essay will reveal the manipulations (rewriting, refraction, adaptation, simplification) that were applied to the original in order to make it acceptable to the horizons of expectation of various Polish target readerships (secondary school pupils, undergraduate students, experienced readers and specialists).

\section{METHODOLOGY}

The retranslations will be analysed using the methodology of the Manipulation School and its development by André Lefevere. Theo Hermans, who coined the term of manipulation in literary and translation studies, expounded the new concept in the introduction to a groundbreaking collection of essays:

The theory of the polysystem sees literary translation as one element among many in the constant struggle for domination between the system's various layers and subdivisions. [...] From the point of view of the target literature, all translation implies a degree of manipulation of the source text for a certain purpose. ${ }^{4}$

Lefevere further develops this approach and convincingly demonstrates in his seminal study Translation, Rewriting, and the Manipulation of Literary Fame that works of literature are re-written in different ways in various cultures due to various factors and constrains: "The non-professional reader increasingly does not read lit-

3 A. Moc, "Nowe prawo autorskie a kolejne thumaczenia na naszym rynku wydawniczym, czyli przygody Pinocchia albo Pinokia" [in:] Między oryginałem a przekładem, vol. 3: Czy zawód tlumacza jest w pogardzie?, eds. M. Filipowicz-Rudek, J. Konieczna-Twardzikowa, M. Stoch, Kraków: Universitas, 1997, p. 181-189; K. Fordoński. "Polski przekład literacki w warunkach wolnego rynku. Spojrzenie nieobiektywne, prowokacyjne i stronnicze”, Przektadaniec 2000, vol. 7, pp. 131-149.

${ }^{4}$ T. Hermans, "Introduction. Translation Studies and a New Paradigm" [in:] The Manipulation of Literature. Studies in Literary Translation, ed. T. Hermans, London \& Sydney: Croom Helm, 1985, p. 11 (emphasis added). 
erature as written by its writers, but as rewritten by its rewriters". 5 Lefevere treated translation, criticism, editing and historiography as form of "refraction" or "rewriting". Translation is the most obviously recognizable and influential type of rewriting "because it is able to project the image of an author and/or a (series) of work(s) in another culture". ${ }^{6}$ By rewriting he meant "translation, editing, and anthologization of texts, the compilation of literary histories and reference works, $[\ldots]$ writing biographies and book reviews [...]." ${ }^{77}$ These mediated forms are produced against various constraints, such as current literary modes of writing and poetics, not to mention economic factors. Rewriters created images of a writer, a work, a period, a genre, sometimes even a whole literature. Lefevere argues that "A writer's work gains exposure and achieves influence mainly through "misunderstandings and misconceptions," or, to use a more neutral term, refractions. Writers and their work are always understood and conceived against a certain background or, if you will, are refracted through a certain spectrum [...]." ${ }^{\prime 8}$ Lefevere's concepts of re-writing and refraction (remodeling of the work according to the audiences's horizons of expectations, or the dominant target culture poetics) will be used to explain the differences in the Polish variants of Heart of Darkness in synchronic perspective. In this essay I would like to scrutinize these factors which directly influence the construction of the image of Heart of Darkness for the Polish readers.

First I would like to introduce the figures of the translators, then the publishing houses (and publishing series) where the retranslations were brought out and last but not least, the paratexts which accompanied these editions. Marta Skwara rightly observes that the functioning of the work in the national culture depends "not only on its refractions but first and foremost on the critical commentaries (press reviews, or longer critical essays), publisher's promotional measures (press notes, advertising materials), introduction on the school/university reading lists, anthologizing — all that constitutes a complex system of "re-writing" of a given work in a new culture. ${ }^{9}$

\section{VISIBLE TRANSLATOR}

Obviously this section's heading is a reworking of Lawrence Venuti's notion of the "invisible translator". He was the first to examine in detail the style and language of translations into English:

${ }^{5}$ A. Lefevere, Translation, Rewriting, and the Manipulation of Literary Fame, London \& New York: Routledge, 1992, p. 4.

${ }^{6}$ Ibid., p. 9.

${ }^{7}$ Ibid., p. 4.

${ }^{8}$ A. Lefevere, "Mother Courage's Cucumbers: Text, System and Refraction in a Theory of Literature" [in:] The Translation Studies Reader, ed. L. Venuti, New York: Routledge, 2012 (emphasis added).

${ }^{9}$ M. Skwara, Polskie serie recepcyjne wierszy Walta Whitmana [Polish W. Whitman's Reception Series], Kraków: Universitas, 2014, p. 12. All translations into English, unless otherwise noted, are my own. 
A translated text, whether prose or poetry, fiction or nonfiction, is judged acceptable by most publishers, reviewers, and readers when it reads fluently, when the absence of any linguistic or stylistic peculiarities makes it seem transparent, giving the appearance that it reflects the foreign writer's personality or intention or the essential meaning of the foreign text - the appearance, in other words, that the translation is not in fact a translation, but the "original."10

He defined the translator's invisibility as "a weird self-annihilation, a way of conceiving and practicing translation that undoubtedly reinforces its marginal status." 11 The consequence of such policy is the nonpresence of the translator, the translator's "invisibility". In contrast to Venuti, I would like to demonstrate that in the selected retranslations the translators are visible and that their choices mould the text and indelibly stamp it to such an extent that a translation scholar is able to recognize which translator rendered a given variant. Certainly, all the translators had acquainted themselves to a smaller or greater extent with the previous versions which I discussed elsewhere. ${ }^{12}$

Chronologically the first translator to be introduced is Jędrzej Polak. He is an experienced translator from English to Polish and an author of one book Życie jest gejem [Life is a Gay]. He translated not only from the so-called high literature (e.g. W. Faulkner's The Sound and the Fury, E. Hemingway's The Old Man and the Sea), but also popular fiction (e.g. J. Grisham's The Pelican's Brief, B. E. Ellis's American Psycho, A. C. Clark's A Space Odyssey) and scientific (e.g. N. Goodman's Introduction to Sociology, B. Jelavich's History of the Balcans). He rendered Heart of Darkness for the first time in 1994 for the SAWW publishing house, and later in 2009 he prepared a corrected version under the literary supervision of Przemysław Czapliński, an eminent literary scholar. ${ }^{13}$ This variant will be analysed in the further part of the essay.

The second translator is Barbara Koc (1925-2013) who was a literary historian. She belonged to the 1920s generation fascinated with Conrad's writing which she shared with "older members of her generation, such as the writers Jan Józef Szczepański, Andrzej Braun and Leszek Prorok". ${ }^{14}$ She was a member of Joseph Conrad Society and published works on his biography and oeuvre (e.g. Conrad. Opowieść biograficzna [Conrad. A Biographical Narrative], Polskość Conrada [Conrad's Polishness], "Epifania w twórczości Conrada” [Epiphanies in Conrad's

${ }^{10}$ L. Venuti, The Translator's Invisibility: A History of Translation, $2^{\text {nd }}$ ed., London \& New York: Routledge, 2008, pp. 1-2 (emphasis added).

${ }^{11}$ Ibid., p. 13.

${ }^{12}$ A. Adamowicz-Pośpiech, "Polskie przekłady Jądra ciemności na XXI wiek. Analiza kontrastywna" [Polish Retranslations of Heart of Darkness in XXI Century. A Conrastive Textual Analysis] [in:] Przestrzenie przekładu 2, eds. J. Lubocha-Kruglik, O. Małysa, Katowice: Wydawnictwo UŚ, 2017, pp. 123-135.

${ }^{13}$ J. Polak, "Od thumacza" [Translator's Note] [in:] J. Conrad, Jąro ciemności, transl. J. Polak, Poznań: Vesper, 2009, p. 171.

${ }^{14}$ S. Zabierowski, "In Memoriam Prof. dr hab Barbara Koc", Yearbook of Conrad Studies 2013, vol. VIII, p. 155. 
Writings). ${ }^{15}$ She compiled a seminal volume of memories and recollections about Conrad in Poland-Wspomnienia i studia o Conradzie [Memoirs and Studies on Conrad]. She translated Heart of Darkness (2000) in response, as it seems, to the rendition of Polak which was evaluated as "a missfire" and "misunderstanding". ${ }^{16}$ Similarly to Polak, she translated only one work by Conrad, but contrary to him, she was a specialist in Conrad studies which had an immense influence on her rendition. ${ }^{17}$

The next translator is Patrycja Jabłońska who has translated literary fiction from English (eg. F. H. Burnett's A Little Princess), German (Grimm's Märchen) and Italian (C. Collodi's Pinocchio) for one publishing house-GREG. She rendered Heart of Darkness in 2008 and it was her only translation of Conrad.

The last translator to be presented is Magda Heydel (1969) - a well-known translator and academic lecturer in the Faculty of Polish Studies at the Jagiellonian University. She translated, among others, works by Virginia Woolf, T. S. Eliot, Ted Hughes and Seamus Heaney. She is an editor-in-chief of the Przektadaniec journal and author of two monographs Obecność T. S. Eliota w literaturze polskiej [T. S. Eliot in Polish Literature] and Gorliwość thumacza [The Translator's Zeal]. She co-edited with P. Bukowski a reader in translation studies Wspótczesne teorie przekładu [Contemporary Translation Theories. An Anthology]. Similarly to Polak and Jabłońska she translated only one work by Conrad, Heart of Darkness (2011) which does not remain without influence on the process of translation of a given author as Susan Basnett has perceptively shown. ${ }^{18}$

\section{THE PUBLISHING CONTEXT}

The translation by Polak (the second variant) was brought out in a small publishing house "Vesper" in Poznań in the "Literary Masterpieces" series. In this series there were also published such works as: R. L. Stevenson's The Strange Case of Dr. Jekyll and Mr. Hyde, Jerome K. Jerome Three Men in a Boat, J. Cleland's Fanny Hill or Memoirs of a Woman of Pleasure. Covers in this series are black with white headings and a picture in the middle. The photo shows the river's bank with several steamships from which the natives pour out. In the background one can see the straw huts of the aborigines. Undoubtedly, it relates to the plot of the tale. On the back cover

${ }^{15}$ K. Batora, "Koc Barbara” [Biographical Note] [in:] Wspótcześni polscy pisarze i badacze literatury: stownik biobibliograficzny, vol. 4, eds. J. Czachowska, A. Szałagan et al., Warszawa: Wydawnictwa Szkolne i Pedagogiczne, 1996, s. 167.

16 "Od wydawcy” [Publisher's Note] [in:] J. Conrad, Jądro ciemności, Warszawa: Ludowa Spółdzielnia Wydawnicza, 2000, p. 7.

${ }^{17}$ See A. Adamowicz-Pośpiech, "Polskie przekłady Jądra ciemności na XXI wiek”, op. cit.

${ }^{18}$ Susan Bassnett claimed that the writings of a given author constitute a subtle net of intertextual links (references to other works by the same author, e.g. key words) which should be translated always in the same way. Hence Bassnett proposes that ideally one translator should render the works of a given author. (S. Bassnett, Translation Studies, London \& New York: Routledge, 1998.) 
there is a blurb with an excerpt from Przemysław Czapliński's "Afterword" accentuating the book's shocking potential and its belonging to the literary cannon.

The rendition by Koc came out in Ludowa Spółdzielnia Wydawnicza [Folk Publishing Cooperative] in 2000. On the dark blue cover there is an overexposed silhouette of a three-mast sailing vessel along with its blurred reflection in the water's surface. At the top of the cover we can see the title and the author's name typed in an indistinct font. The vague reflection of the vessel may suggest the modernist narration of the story or the epistemological problems. Likewise, the indistinct font may signal the difficulties in recording and conveying Marlow's experience. On the back cover we can read a biographical note. This translation will be analysed as the second one because in the "Publisher's Note" there is a reference to Polak's first version of Heart of Darkness (published in 1994).

Jabłońska's edition's cover is the most colourful and the least ambiguous: everything is clearly presented. The author of the cover design is Jolanta Ludwikowska. In the top left corner there is the writer's name and just opposite in capital letters the label "Obligatory Reading with additional notes"; beneath there is the title highlighted in yellow. In the central part of the cover there are heavily ornamented black heads, below there is a typical colonial English headwear placed on the leather-bound notebook with a sharpened pencil next to it. In the bottom right corner there is a red spiky circle with the label "easy-to-read font". These elements allude to stereotypical images of black tribes in Africa and the colonizers and all that should, in the publisher's perspective, trigger typical associations which a young (inexperienced) reader has with African culture and its nineteenth century colonizers. Definitely the cover is targeted at a young audience which is confirmed by the "Obligatory Reading" label. ${ }^{19}$ On the back cover there are some other cover illustrations of other books published in this series (e.g. A. Mickiewicz's Ballady i romanse, W. Reymont's Chłopi, Sopholes's Oedipus King and F. Kafka's Trial).

The translation by Heydel was included in the $50 / 50$ series (that is 50 books for the $50^{\text {th }}$ anniversary of Znak Publishing House). Znak is a renowned publishing company in Poland with long publishing history as well as some historical merits for resistance to the communist regime. The series was advertised as "the best guide in the world of literature; prominent authors, important works [...]. The 50/50 series contains books which simply you have to know" In this series the following volumes were published: Moliere's Tartuffe, F. S. Fitzgerald's Great Gatsby, A. Dumas The Three Musketeers in new and "outstanding" retranslations as the publisher affirms in the promotional materials. ${ }^{20}$ Heydel for her rendition of Heart of Darkness received a prestigious award for "The Best Translation of the Year" (2012) granted by Literatura na Świecie (World Literature), a noted literary periodical. On the greybrown cover designed by Kuba Sowiński one can see in the centre a wooden ruler on whose jagged edges a tiny steamship "moves". It may symbolize the steamship's journey up the Congo river frought with danger. In the background at the top we can

\footnotetext{
${ }^{19}$ In Poland Heart of Darkness is on the high school reading list, scheduled for seventeen-year-old students as well as on university reading lists for undergraduate students.

${ }^{20} \mathrm{https}: / /$ www.znak.com.pl/kartoteka,ksiazka,4547
} 
see faded handwriting in French. Maybe these are Joseph Conrad-Korzeniowski letters written to his friends when he was in Africa? On the back cover there is some information about the 50/50 series, the novella and a short biographical note about Conrad. As regards the information about the book there is a concise but powerful sentence: "A harrowing and dangerous masterpiece in a new translation". We can discern several similarities to the back cover note on Polak's edition, in which also the key-word "masterpiece" was used and analogously it was qualified as "dangerous". In both editions the power of this novella was accentuated along with its subversive character which seems to be a deliberate promotional gimmick encouraging the potential clients to purchase the book.

Additionally, on the back cover, there is a brief summary emphasizing again the controversial quality of Marlow's story, its modernity and significance for contemporary readers. In the last sentence it was repeated that it is a new rendition accompanied by an "excellent" afterword. Taking these notes into consideration, one can surmise that similarly to Polak's edition, it is a publication targeted at an adult and experienced reader. The questions posed by the editor (e.g. about the origin of evil, man's identity, the concept of the Other) are complex philosophical issues. The films by F. Coppola and W. Herzog mentioned in the blurb, likewise, are addressed to mature audience. However, this note on the back cover, contrary to Polak's, is overloaded with information which puts a strain on the reader.

\section{PARATEXTS OF TRANSLATION}

Refraction according to Lefevere may occur on many levels and in many different ways. In this essay I would like to focus on one mode of refracting the translated text in the target culture - on paratexts of translation. Gérard Genette was the first to broaden our understanding of the "undefined zone" between the inside and the outside of a text/book: „The paratext is what enables a text to become a book and to be offered as such to its readers and, more generally, to the public". ${ }^{21}$ Paratexts are not neutral and transparent, quite the opposite, they "control one's whole reading of the text". ${ }^{22}$ They constitute a "zone of transition and of transaction": a place of an influence that "is at the service of a better reception for the text and a more pertinent reading of it (more pertinent, of course, in the eyes of the author and his allies". ${ }^{23}$ Genette observed that paratexts have "spatial, temporal, substantial, pragmatic and functional characteristics". ${ }^{24}$ The most visible types of paratexts of translation include translator's prefaces and afterwords, footnotes as well as critical interpretative essays ac-

${ }^{21}$ G. Genette, Paratexts: Thresholds of Interpretation, transl. J. E. Lewin, Cambridge: Cambridge UP, 1997, p. 1. For a detailed discussion of paratexts of translation see E. Skibińska (ed.), Między oryginałem a przekładem, vol. 17: Parateksty przekładu, Kraków: Księgarnia Akademicka, 2011, pp. 5-10.

${ }^{22} \mathrm{Ph}$. Lejeune, Le Pacte autobioghraphique (1975), p. 45. Qtd. in G. Genette, Paratexts, op. cit., p. 2.

${ }^{23}$ G. Genette, Paratexts, op. cit., p. 2.

${ }^{24}$ Ibid., p. 4. 
companying a given edition, press reviews and promotional materials. ${ }^{25}$ Less visible, but equally powerful types of paratexts are the titles and subtitles, chapter headings, and blurbs on back covers or dust jackets. Each type of these paratexts influences the reader, sometimes quite imperceptibly. ${ }^{26}$

The key observations of Genette relating to the idea of refraction in translation which is the subject of the essay, are the remarks that paratexts are purposeful, represent a well thought-out strategy (publisher's, editor's or translator's) and intentionally profile the text's reception (it is to be a "proper" reading, in other words desired or projected by the translator's interpretation of the work). All these types of paratexts are to a bigger or lesser extent present in the case of Heart of Darkness and refract its reception in Poland.

At first it must be stressed that the number of paratexts accompanying the four editions varies greatly, from few ones (in the case of Koc's) to a great number (in the case of Heydel's). The editions by Jabłońska and Heydel epitomize to the utmost Lefevere's observations on refraction on various levels, hence they shall be discussed as the first ones. Jabłońska's rendition inscribes Heart of Darkness in the educational obligatory-reading scheme. If so, what does it look like? On the basis of the survey of 30 editions of school required-reading books the following features can be distinguished: distinct information on the front cover or first page about the book's status (required-reading), study guides attached to the core text (they include among others, short interpretative essays, summary, lists of protagonists (their characteristics), important quotations, suggested composition topics. In most of the surveyed publications all the critical notes are located after the text proper. ${ }^{27}$ In GREG edition, however, the commentaries are incorporated in the main text in boxes with a grayish background and printed in bold font which disrupts in a significant way the reading process. In case of such a layout (which constitutes an example of non-verbal para$t^{28}{ }^{28}$ ) the question arises: which of the graphically marked out excerpts or the text around them is the core text and which the paratext?

In Jabłońska's version four types of commentaries can be distinguished:

1. concise synopsis of the events (e.g. "Marlow's journey route" (J 14); "the Accountant on Kurtz" (J 19));

2. signaling key quotations (e.g. "Important quote: Kurtz" (J 24); "Important quote: whites impunity, lawlessness" (J 31));

${ }^{25}$ These are just selected types of paratexts. The full classification is given by E. Skibińska (ed.), op. cit., pp. 7-9.

${ }^{26}$ K. Harvey, “'Events' and 'Horizons': Reading Ideology in the 'Bindings' of Translations” [in:] Apropos of Ideology: Translation Studies on Ideology - Ideologies in Translation Studies, ed. M. Calzada Pérez, Manchester: St. Jerome, 2003, pp. 43-70.

${ }^{27}$ The following publishing series were surveyed: Lektury Szkolne (Adalex Publishing House), Biblioteka Lektur Szkolnych (Wydawnictwo Lódzkie), Biblioteka Lektur Szkolnych (Wydawnictwo Literackie), Lekcja Literatury (Wydawnictwo Literackie), Lektura z Opracowaniem (Spes Publishing House), Biblioteka Lektur Szkolnych (Interart Publishing House).

${ }^{28}$ Apropos of Ideology, op. cit. 
3. signaling intertextual references (e.g. "allusion to inferno - a part of Dante's Divine Comedy" (J 17));

4. highlighting the symbolic fragments or main motifs of the novella (e.g. "Symbolism": the Parcae (Fates) (J); "palisade with the Negroes heads—-symbol of Kurtz's work" (J); "the motif of darkness" (J)).

These grayish boxes break the novella's coherence and atomize the text proper. In general there are from one to four comments in boxes per page while on sixty four pages of the translation there are only fifteen pages without them.

the main text of Heart of Darkness

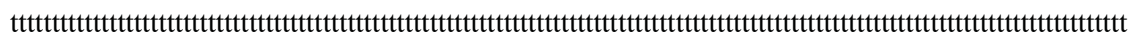
ttttttttttttttttttttttttttttttttttttttttttttttttttttttttttttttttttttttttttttttttttttttttttttttttttttttttttttttttttttt

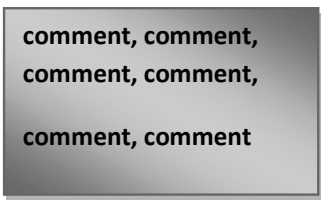
tttttttttttttttttttttttttttttttttttttttttttttttttttttttttttttttttttttttttttttttttttttt ttttttttttttttttttttttttttttttttttttttttttttttttttttttttttttttttttttttttttttttttttttttt ttttttttttttttttttttttttttttttttttttttttttttttttttttttttttttttttttttttttttttttttttttt tttttttttttttttttttttttttttttttttttttttttttttttttttttttttttttttttttttttttttttttttt tttttttttttttttttttttttttttttttttttttttttttttttttttttttttttttttttttttttttttttttttttttttttttttttttttttttttttttttttttttttt tttttttttttttttttttttttttttttttttttttttttttttttttttttttttttttttttttttttttttttttttttttttttttttttttttttttttttttttttttttttttttttt ttttttttttttttttttttttttttttttttttttttttttttttttttttttttttttttttttttttttttttttttttttttttttttttttttttttttttttttttttttttt ttttttttttttttttttttttttttttttttttttttttttttttttttttttttttttttttttttttttttttttttttttttttttttttttttttttttttttttttttttt tttttttttttttttttttttttttttttttttttttttttttttttttttttttttttttttttttttttttttttttttttttttttttttttttttttttttttttttttttttttttttttt tttttttttttttttttttttttttttttttttttttttttttttttttttttttttttttttttttttttttttttttttttttttttttttttttttttttttttttttttttttttttttt tttttttttttttttttttttttttttttttttttttttttttttttttttttttttttttttttttttttttttttttttttttttttttttttttttttttttttttttttttt ttttttttttttttttttttttttttttttttttttttttttttttttttttttttttttttttttttttttttttttttttttttttttttttttttttttttttttttttttttttttttt ttttttttttttttttttttttttttttttttttttttttttttttttttttttttttttttttttttttttttttttttttttttttttttttttttttttttttttttttttttttttttttt ttttttttttttttttttttttttttttttttttttttttttttttttttttttttttttttttttttttttttttttttttttttttttttttttttttttttttttttttttttttttttt tttttttttttttttttttttttttttttttttttttttttttttttttttttttttttttttttttttttttttttttttttttttttttttttttttttttttttttttttttttt

comment, comment,

comment, comment,

comment, comment tttttttttttttttttttttttttttttttttttttttttttttttttttttttttttttttttttttttttttttttttttttttttt tttttttttttttttttttttttttttttttttttttttttttttttttttttttttttttttttttttttttttttttttttttttttt ttttttttttttttttttttttttttttttttttttttttttttttttttttttttttttttttttttttttttttttttttttttttttt ttttttttttttttttttttttttttttttttttttttttttttttttttttttttttttttttttttttttttttttttttttttttt tttttttttttttttttttttttttttttttttttttttttttttttttttttttttttttttttttttttttttttttttttttttttttttt

tttttttttttttttttttttttttttttttttttttttttttttttttttttttttttttttttttttttttttttttttttttttttttttttttttttttttttttttttttttttttttttttttt ttttttttttttttttttttttttttttttttttttttttttttttttttttttttttttttttttttttttttttttttttttttttttttttttttttttttttttttttttttttttttttttttt tttttttttttttttttttttttttttttttttttttttttttttttttttttttttttttttttttttttttttttttttttttttttttttttttttttttttttttttttttttttttttttttttt ttttttttttttttttttttttttttttttttttttttttttttttttttttttttttttttttttttttttttttttttttttttttttttttttttttttttttttttttttttttttttttttt tttttttttttttttttttttttttttttttttttttttttttttttttttttttttttttttttttttttttttttttttt

Fig. 1. An example page of Jabłońska's translation with the inserted comments in the boxes 
It can be concluded that in the case of Greg's edition the morphology of the text is divided into the text proper (authorial) which covers three quarters of the publication and side text (added by the translator/editor) which is almost one fourth of the book. Apart from the visual function of disrupting the reception of the text due to the artificial setting apart of small interpretative and semantic entities, the function purposefully projected by the editor is a simplification of the process of reading and understanding of the text. Because of these brief commentaries, the editor (or the translator) simplifies the tale, in other word, he applies the technique contrary to the intentio auctoris. ${ }^{29}$

Space considerations do not permit us here to discuss all cases of simplification, hence three examples would have to suffice. During the journey up the river Marlow's boat is attacked by the natives with thin arrows. However Marlow at the beginning cannot recognize it because of several reasons: overwork, fog, concentration on gauging the river's depth, hence he sees only "sticks" swishing in the air. By recording these uninterpreted observations Conrad reflects one of the creative purposes of impressionism and modernist esthetics: to describe the most primal sensation before human attempt at rationalization is brought to bear. ${ }^{30}$ The reader, likewise, should be confused and uncertain what really happens and in result wrongly interpret the signs of the surrounding reality. It is an instance of the impressionistic method of narration based on "delayed decoding" ${ }^{31}$ However, the Polish editor inserts the comment box-

${ }^{29}$ The narration of Heart of Darkness is deliberately incoherent and inconclusive since it stems from the modernist esthetics. This distinctive narrative feature had been amply analysed by I. Watt, Conrad in the Nineteenth Century, Berkeley: University of California Press, 1981. See also: R. Kimbrough, Conrad's Heart of Darkness: An Authoritative Text, Backgrounds and Sources Essays in Criticism, London \& New York: Norton \& Company, 1988, pp. 311-345; J. Lothe, Conrad's Narrative Method, Oxford \& New York: Clarendon Press, 1989; A. Simmons, Conrad's Heart of Darkness, London: Continuum, 2007, pp. 21-39.

${ }^{30}$ Virginia Woolf described much later similar aims of a self-conscious modernist writer aiming at recording the essence of life: "The mind receives a myriad impressions - trivial, fantastic, evanescent, or engraved with the sharpness of steel. From all sides they come, an incessant shower of innumerable atoms; and as they fall, as they shape themselves into the life of Monday or Tuesday, the accent falls differently from of old; the moment of importance came not here but there; so that, if a writer were a free man and not a slave, if he could write what he chose, not what he must, if he could base his work upon his own feeling and not upon convention, there would be no plot, no comedy, no tragedy, no love interest or catastrophe in the accepted style, and perhaps not a single button sewn on as the Bond Street tailors would have it. Life is not a series of gig lamps symmetrically arranged; life is a luminous halo, a semi-transparent envelope surrounding us from the beginning of consciousness to the end. Is it not the task of the novelist to convey this varying, this unknown and uncircumscribed spirit, whatever aberration or complexity it may display, with as little mixture of the alien and external as possible?" (V. Woolf, "Modern Fiction" [in:] Modernism and Literature, eds. M. Carter, A. W. Friedman, New York: Routledge, 2013, p. 475.)

${ }^{31}$ Watt explains the purpose of this technique: "Heart of Darkness embodies more thorough than any previous fiction the posture of uncertainty and doubt; one of Marlow's functions is to represent how much a man cannot know [...]. This narrative device may be termed delayed decoding, since it combines the forward temporal progression of the mind, as it receives messages from the outside world, with the much slower reflexive process of making out their meaning. Through this device $[\ldots]$ the reader participates in the instantaneous sensations [...]. [It] was the verbal equivalent of the impressionistic painter's attempt to render visual sensation directly. Conrad presented the protagonist's immediate sensations, and thus made the reader aware of the gap between impression and understanding [...]. Conrad's device of delayed 
es in bold about the natives' attack above the main text and thus spoils the modernist narrative technique. Such clear-cut notes transform the deliberately sophisticated mode of narration into uncomplicated adventure story for young readers. ${ }^{32}$

A slightly different type of simplification takes place at the description of Kurtz's station. Marlow approaches it very cautiously and scans the horizon with his binoculars. He is surprised to see ornamental balls on the tops of fence posts surrounding the station because the main house was dilapidated. Coming closer to the river bank he is shocked to recognize that the wooden ornaments were actually poles topped with severed human heads. In this case again pure recording of perception and the technique of delayed decoding should make "the reader aware of the gap between impression and understanding; the delay in bridging the gap enacts the disjunction between the event and the observer's trailing understanding of it". ${ }^{33}$ Hence while reading the story, the reader should be led astray as Marlow was, and misinterpret the balls as decorations, only later to discover with horror that these were human heads. Yet, if there is a box with a note in bold type: "Palisade with savages' heads" (J 52) immediately catching the reader's attention on the page, we cannot expect neither faulty interpretation nor the effect of agitation on the part of the reader. Once again the deliberately applied narrative technique was rendered void by the specific procedure of text edition.

Last but not least, an example which is not only a case of simplification but also of misunderstanding (overlooking irony). Let us have a closer look at the passage since it is crucial in Conrad's critique of imperialism.

In a few days the Eldorado Expedition went into the patient wilderness, that closed upon it as the sea closes over a diver. Long afterwards the news came that all the donkeys were dead. I know nothing as to the fate of the less valuable animals. (C 182; emphasis added)

The expression "less valuable animals" refers to the European participants of the expedition and is obviously used ironically. It is the task of the reader to decode the irony. ${ }^{34}$ This fragment is so important because it reveals indirectly Marlow's attitude towards the politics of colonization. Yet, in the Polish edition, there is a succinct comment interwoven in bold into the paragraph which unequivocally informs the readers of the opposite meaning of Marlow's comment: "Negroes_less precious animals" (J 32). Definitely it is an erroneous reading which is authoritatively imposed on the young reader.

As far as the extra texts attached to this edition are concerned, they include a short biography of Conrad, some information about the genesis of the work, the explication

decoding represents an original narrative solution to the general problem of expressing the process whereby the individual's sensations of the external world are registered and translated into causal and conceptual terms which can make them understandable to the observer and communicable to other people". (I. Watt, "Impressionism and Symbolism in Heart of Darkness" [in:] R. Kimbrough, op. cit., pp. 316-19.)

${ }^{32}$ Another publisher went even further: he numbered particular sections of the story, inserted appropriate headings and thus ordered Marlow's chaotic narration. (J. Conrad, Jądro ciemności, Warszawa: Buchmann, 2011.)

${ }^{33}$ I. Watt, "Impressionism and Symbolism in Heart of Darkness", op. cit., p. 317.

${ }^{34}$ C. Watts, "Introduction", op. cit., p. xxiii. 
of the title, the novella's composition, main themes, impressionism and symbolism, the socio-political and moral problematic as well as the list of important quotations. The form of the commentary is simple and comprehensible; undoubtedly prepared with the teenage audience in mind. In light of the above, there arises the question whether we shouldn't raise the standards and demand more form the young readers? The fact of placing Heart of Darkness on the obligatory reading list should not amount to maximal simplification of the text and getting rid of indeterminacies and understatements. Exactly this form of refraction can be observed in the case of Jabłońska's translation in Greg edition.

The other retranslation which is accompanied by a great number of paratexts is Magda Heydel's version brought out by Znak Publishing House. In this case one can distinguish a whole spectrum of paratexts starting with the more traditional "Afterword" through press reviews to current media coverage: internet interviews, literary festival debates and granted awards. As I have already stated, both retranslations (Jabłońska's and Heydel's) exhibit most intensive refraction. In the case of Jabłońska, these are commentaries intertwined with the novella's text whereas in the case of Heydel's it is an extensive "Afterword" and wide media coverage. The following types of media campaign can be noted: publishing house advertising and promotion, press articles and notes (sometimes of a covert promotional function), interviews in the internet, public debates and awards granted for the translation (which once again produced an echo in the media).

Let us begin with the most easily available and very influential paratext since it was published along with the translation, i.e. the "Afterword". It must be stressed that the translators' afterwords or forewords profile the reception of the text they are referring to; even more so in this case because the voice of the translator is a voice of a well-known translation studies scholar whose "name in the logic of the publishing house promotion attracts to the book as much as the name of the original author". ${ }^{35}$ The "Aferword" is very dense and undoubtedly dedicated to an experienced reader (Lefevere calls such readers "professionals" ${ }^{36}$ ) since it contains a comprehensive survey of the novella's reception history: the interpretations of A. Guerard, I. Watt, postcolonial and feminist, among others. The postcolonial and the feminist readings are presented as ones out of many. They should not constitute the centre of reception and they do not in Heydel's "Afterword".

Another type of paratext is the information located in the media. The scope of the essay does not allow for the presentation of all the forms of media coverage, thus I will concentrate on its selected but distinctive aspects. Firstly, press articles in opinion forming dailies (Gazeta Wyborcza, Rzeczpospolita), weeklies (Tygodnik Powszechny) and literary periodicals (Literatura na Świecie). Most of these articles are brief texts with a well thought-out layout, illustrated with the book's cover and

\footnotetext{
${ }^{35}$ A. Cetera, "Przypomnienie tłumacza: rzecz o elementach meta przekładu we współczesnych prozy angielskiej” [in:] Warsztaty translatorskie IV, eds. E. Sokoloski et al., Lublin \& Ottawa: KUL, p. 101.

${ }^{36}$ Lefevere used the term to designate literary critics, teachers, and students of literature (A. Lefevere, Translation, Rewriting, and the Manipulation of Literary Fame, op. cit., p. 3.)
} 
indirect promotional function. ${ }^{37}$ Just one example: Lektor in the review of Heart of Darkness in Tygodnik Powszechny represents the intuitive and impressive critique by repeating such clichés as "the translation reads fluently", "it's well written". ${ }^{38}$ Likewise, the reviewers in Gazeta Wyborcza and Rzeczpospolita praise the style of the translation without reference to the original.

A different type of translation criticism is represented by Jerzy Jarniewicz in Literatura na Świecie. His essay could serve as a model for an in-depth translation critique when the critic knows the language of the original and compares and contrasts the new retranslation both with the original and with the previous translations. Jarniewicz compared Heydel's variant with Polak's and Zagórska's but the most significant point he made was, in my opinion, pointing to Heydel's creative approach to translation in result of which she "tunes her rendition so as to highlight the closest to her sensitivity interpretative strand and this strand will find its reflection in her translational choices and decisions". ${ }^{39}$ This tallies with Heydel's own pronouncements in which she stresses that translation is interpretation and a point of departure for the translator's creativity: "I believe that the original is not an absolute, that it is only a problematic point of departure. No semantics of a translation unit is given to us once and for all. No sentence means always the same. Hence the original is for me a net with large mesh, the original is a text that spurs you to a creative act" ${ }^{40}$

Another form of media campaign constitute the translator's reviews in which he/ she reveals the arcane aspects of the translators' work. ${ }^{41}$ In these interviews she confirms Jarniewicz's observations as regards her creative approach towards the translated text: "My intention was to read anew one of the masterpieces of the last century, to show how it can be read today [...]. I wanted very much to relate Conrad's novella to its contexts; and to show the translator's work not only as stylistic and technicallylinguistic. Additionally in her interviews Heydel develops some of interpretations outlined in the "Afterword". In the media she accentuates only two interpretative paths: postcolonial and feminist. Heydel admits in one of the internet interviews:

Heart of Darkness is a novel which locates itself right in the centre of postcolonial interpretations of the Western literary canon. [...] It wasn't so when the original was written, was it? So we can't say that the postcolonial interpretations stem from the original or from the so called

${ }^{37}$ B. Marzec, "Conrad o podróży do granic cywilizacji”, http://www.rp.pl/artykul/696923-Conrad-opodrozy-do-granic-cywilizacji.html\#ap-1 (access: 4.08.2011); Lektor, Recenzja Jądra ciemności [Review of Heart of Darkness], http://ksiazki.onet.pl/recenzje/recenzja-jadro-ciemnosci-joseph-conrad/hvb2s.

${ }^{38}$ This form of superficial criticism relating to translated works was perceptively analysed by L. Venuti, The Translator's Invisibility, op. cit., pp. 7-14.

${ }^{39}$ J. Jarniewicz, “...i inne głosy” [Review of Heart of Darkness], Literatura na Świecie 2012, no. 9-10, p. 421.

${ }^{40}$ M. Heydel [in:] P. Sommer, "Czy ja robię refrakcję? O antologii Wspótczesne teorie przekładu" [dyskusja w redakcji „Literatury na Świecie”, P. Bukowski, M. Heydel, J. Jarniewicz et al.], Literatura na Świecie 2012, vol. 3-4, p. 366.

${ }^{41}$ A. Wąsowicz, "Pamiętaj, przekład wszystko zmienia", http://www.e-splot.p1/?pid=articles\&id=2723 (access: 2.09.2014); M. Heydel, "Trzymam gardę" [in:] Przejęzyczenie: rozmowy o przektadzie, ed. Z. Zaleska, Wołowiec: Wydawnictwo Czarne, 2015, pp. 271-300. 
intentio auctoris. If in my translation one can trace the awareness of where we are now and from what perspective we read Conrad today, then I'll be very happy. ${ }^{42}$

In another interview, Heydel emphasises the feministic perspective in translation:

Heart of Darkness is a novel that could be interestingly read from the feministic angle, not only in the context of Kurtz's Intended who waits in Europe and whom Marlow visits at the end to tell her that Kurtz's last words were her name. There are interpretations which state that this is a picture of women's isolation, closing them in a bubble of illusion and not allowing them to participate in real life. Apportioning such place to women by men under the pretext of protecting them from the world's evil is a significant theme which can be interpreted from the feministic perspective. Thus Europe is for women and Africa [...] is a man's world. ${ }^{43}$

It is these pronouncements that manipulate the reception in a greater degree than the translation itself or the "Afterword". Foregrounding only these two interpretative paradigms (postcolonial and feminist) in various media, locate this work in a particular ideological context. Paradoxically, the "Afterword" on its own does not impose such interpretations. It is only the pronouncements in media that do it. Therefore, in my opinion, the manipulation of the text occurred in the media campaign and the work was refracted to fit into a specific interpretative and ideological slot.

To recapitulate this part of the analysis, it is the translator's secondary utterances (interviews, public debates) that narrow down the novella's reception and interpretation and refract the text in Polish culture whereas the "Afterword" itself is an extensive and insightful overview of the tale's history of reception.

Undoubtedly, the analysed examples testify to a wide media campaign ${ }^{44}$ in which "the translator's duel with the text became an independent story, rivaling with the translated work's plot". ${ }^{45}$ It is a relatively new phenomenon taking place firstly, in the case of large publishing houses which can afford expensive promotional campaigns; secondly, in the case of culturally significant works (e.g. the new translation of Goethe's Faust) and thirdly, in the case of well-known translators (e.g. Antoni Libera's translations of S. Beckett, Jerzy Jarniewicz"s translations of J. Joyce, M. Heydel's translations of V. Woolf). To close this stage of analysis one has to answer the question: how does it influence the translation itself? It seems that as a result of the translator's presence in the media refraction occurs or in other words a purposeful and unique manipulation can be observed which profiles the text's reception. In the case of Heydel's translation, the text, firstly, was located in a specific interpretative context, and secondly, it was targeted at a selected audience (undergraduate students, teachers, critics, in other words "professionals").

${ }^{42}$ A. Wąsowicz, "Pamiętaj, przekład wszystko zmienia”, op. cit. Cf. also M. Heydel, "Trzymam gardę", op. cit.

${ }^{43}$ A. Wąsowicz, "Pamiętaj, przekład wszystko zmienia", op. cit.

${ }^{44}$ Another echo in the media was caused by the reward for translation granted to M. Heydel by the renown literary magazine Literatura na Świecie [World Literature]. This event was covered by the mainstream media.

${ }^{45}$ A. Cetera, "Przypomnienie thumacza", op. cit., p. 96. 
Polak's and Koc's editions place themselves at the other extreme as far as media refraction is concerned. Contrary to Jabłońska's or Heydel's variants, one can observe there a much higher number of microrefractions in the text itself. ${ }^{46}$

Polak's rendition is accompanied by an afterword entitled "A Dangerous Masterpiece" written by an eminent Polish literary critic, Przemysław Czapliński. Although, similarly to the "Afterword" by Heydel, it includes a short Conrad's biography and an outline of reception of Heart of Darkness, it differs remarkably with respect to emphasising various interpretative perspectives. When Czapliński discusses a given interpretation first of all, he lays bare the critic's ideological bias (Marxist, imperialistic or postcolonial, among others). For one thing, Czapliński believes that the postcolonial interpretation is a form of the novella's influence on its readers:

All of us in a way participate in the debate on Conrad's racism since-we feel-Heart of Darkness still models our perception of the world, and if we are affected by it, we accept all the categories and metaphors which belong to it. ${ }^{47}$

Having outlined Ch. Achebe's arguments, Czapliński proceeds to a persuasive polemics with the Nigerian novelist based on close reading of Heart of Darkness. ${ }^{48} \mathrm{In}$ conclusion he claims: "I don't know any other text which so successfully would lead to an implosion of the colonial discourse." ${ }^{49}$ However, the crucial component of Czapliński's essay is proposing his own reading of the tale in the context of European literature which I will discuss in more detail because of the refraction it causes. Undoubtedly, it is a form of refraction, in Lefevere's understanding of the term, consisting in locating Heart of Darkness in the context of European masterpieces; even the title itself - "A Dangerous Masterpiece"-unequivocally states that. Contrary to Achebe's adverse verdict: "Should this novel be called a great masterpiece of art? My answer is: "No; no, it shouldn't," ${ }^{50}$ Czapliński discusses the tale with reference to selected literary masterpieces which undertake the theme of lack of God and the ensuing lack of codex of ethical norms. The selection of the masterpieces is significant here: Dostoevsky's The Possessed, Nietzsche's Joyful Wisdom, Kafka's Trial, Camus' The Stranger and Gombrowicz's Cosmos - these are "the texts which make the European canon and at the same time break it". ${ }^{51}$ The scholar views the novella as an analysis of the consequences of man's absolute autonomy; however, what is important, not a unique one, but locating it in a specific chain of philosophical and ethical ruminations undertaken by writers before and after Heart of Darkness. Czapliński argues:

The most insightful and brave writers of the $20^{\text {th }}$ and $21^{\text {st }}$ centuries depicted liminal consequences of man's solitude. They showed protagonists who having reached the crossroads, choose one

\footnotetext{
${ }^{46}$ I discussed them in "Polskie przekłady Jądra ciemności na XXI wiek...".

${ }^{47}$ P. Czapliński, "Niebezpieczne arcydzieło" [A Dangerous Masterpiece] [in:] J. Conrad, Jądro ciemności, transl. J. Polak, Poznań: Vesper, 2009, p. 147.

${ }^{48}$ Ibid., pp. 141-147.

${ }^{49}$ Ibid., p. 147.

${ }^{50}$ Ch. Achebe, “An Image of Africa” (2001), qtd. in P. Czapliński, "Niebezpieczne arcydzieło”, op. cit., p. 135.

${ }^{51}$ P. Czapliński, "Niebezpieczne arcydzieło", op. cit., p. 167.
} 
of the paths: either they go towards complete freedom which no longer has absolute sense or towards the Absolute who will not give them freedom. The world without God is full of horror, and with God full of abomination. Dostoevsky still tried to cope with that: on Raskonikov's path he put Sonia with her humbleness. [...] But Kafka no longer upheld that hope: in The Trial he told the story of Joseph K. who defended his innocence only to understand that the existence of God means the admission of guilt. [...] Kurtz likewise, epitomizes the consequences of man's drive to total autonomy. The consequences are clear: independence from moral judgement, instrumental approach towards the other human being, mingling mission with criminality. ${ }^{52}$

Due to such interpretation of Heart of Darkness Czapliński places this work in the well established tradition of philosophical and ethical meditations on the nature and genesis of morality. Marlow's story unravels in the world without values and principles of behavior and "is an answer to a situation when a man can do everything with the other". ${ }^{53}$ But then - Czapliński concludes - "there arise the rudiments of ethics when man being like God, curtails his own freedom". ${ }^{54}$ The refraction that can be observed in this case consists in positioning this translation in the context of meditations concerned with the foundations of autonomic ethic and, in broader perspective, in locating Heart in Darkness in the tradition of ethical interpretations.

Koc's translation except for a concise note "From the Publisher" does not contain any translator's comments. Significantly, however, in this short note Polak's rendition was criticized, hence implicitly Koc's variant was shown as the proper one, correcting its predecessor's errors. Koc published one critical essay on Heart of Darkness in which she used quotations from her own translation so I think that we can view it as a supplementary commentary on the novella. ${ }^{55} \mathrm{Her}$ interpretation remains within the tradition of early moral readings of Conrad since she calls him "a moralist". She claims that the work "radiates with moral strength" while Marlow is "a truth seeker". ${ }^{56}$ Unfortunately, she frequently makes the mistake of equating Marlow's judgements and opinions with Conrad's. For instance: "By condemning himself for all eternityConrad states - Kurtz [...] gained moral victory". ${ }^{57}$ This quotations reflects also another drawback of Koc's interpretation; namely formulating definitive conclusions relating to the issues which in the novella are shown as ambiguous and indeterminate. Koc eliminates many textual indeterminacies (hence obliterates the multiplicity of possible interpretations of given textual elements) as well as explicates some issues unclear to Marlow by proposing unequivocal interpretations. Two examples to illustrate this approach will have to suffice: "In the face of the existing love, reverberating in the Intended's bewailing Kurtz, evil and truth seem to suspend their verdicts. Compassion triumphs. ${ }^{" 58}$ According to Koc the ultimate purport of the book is con-

\footnotetext{
${ }^{52}$ Ibid., p. 169.

${ }^{53}$ Ibid., p. 170.

${ }^{54}$ Ibid.

${ }^{55}$ B. Koc, "Jadro ciemności w stulecie istnienia" [The Centenary of Heart of Darkness], Przeglad Humanistyczny 2000.

${ }^{56}$ Ibid., p. 108.

${ }^{57}$ Ibid., p. 111.

${ }^{58}$ Ibid.
} 
solation and hope. The other one is her claim that "Conrad clarified what the role of the station's manager and his uncle was in the story." ${ }^{99}$ Quite the contrary, the uncle's intrigue constitutes one of the covert plots, not understood by Marlow (and the reader) which was convincingly shown by Cedric Watts. ${ }^{60}$

To conclude, Heart of Darkness functions on various levels in Polish culture: as an obligatory reading for school students (Jabłońska's version), as a masterpiece, a book belonging to the literary canon for experienced readers (Polak's and Heydel's renditions) and as a form of polemics with the previous retranslation (Koc's variant). The original was refracted and re-written into divergent copies for different audiences. It would be good if the reader who wants to read Heart of Darkness knew that they would be reading a deliberately profiled version. The analysis was to highlight the types of refraction to help the readers to make a conscious choice.

\section{WORKS CITED}

\section{Primary bibliography}

The translations of Heart of Darkness analysed in the essay:

Conrad, J., Jądro ciemności, transl. J. Polak, Poznań: Vesper, 2009. (P) 2000. (K)

----------, Jądro ciemności, transl. P. Jabłońska; oprac. A. Popławska, [il. J. Ludwikowska], Kraków: Greg, 2008. (J)

----------, Jądro ciemności, transl. M. Heydel, Kraków: Wydawnictwo Znak, 2011. (H)

\section{Secondary bibliography}

Achebe, Ch., "An Image of Africa" [in:] The Norton Anthology of Theory and Criticism, ed. V.B. Leitch, New York \& London: W.W. Norton \& Co, 2001, pp. 1783-1793.

Adamowicz-Pośpiech, A., "Polskie przekłady Jądra ciemności na XXI wiek. Analiza kontrastywna

[Polish Retranslations of Heart of Darkness in XXI Century. A Conrastive Textual Analysis]

[in:] Przestrzenie przekładu, eds. J. Lubocha-Kruglik, O. Małysa, Katowice: Wydawnictwo UŚ, 2017, vol. 2, pp. 123-135.

Bassnett, S., Translation Studies, London \& New York: Routledge, 1998.

Borges, J. L., "The Translators of the 1001 Nights" [in:] The Translation Studies Reader, ed. L. Venuti, New York \& London: Routledge, 2016.

Cetera, A., "Przypomnienie thumacza: rzecz o elementach meta przekładu we współczesnych prozy angielskiej" [in:] Warsztaty translatorskie IV, eds. E. Sokoloski et al., Lublin \& Ottawa: KUL, 2007, pp. 89-104.

Conrad, J., Heart of Darkness, ed. R. Kimbrough, New York: Norton, 1988.

----------, Heart of Darkness and Other Tales, Oxford: Oxford, UP, 1996.

----------, Jądro ciemności, transl. J. Polak. Poznań: Kantor Wydawniczy SAWW, 1994.

${ }^{59}$ Ibid., p. 112.

${ }^{60}$ C. Watts, "Conrad's Covert Plots and Transtextual Narratives", Critical Quarterly 1982, vol. 24, pp. 53-64. 
-----------, Jądro ciemności [in:] idem, Młodość i inne opowiadania, transl. A. Zagórska, Warszawa: PIW, 1972.

Czapliński, P., "Niebezpieczne arcydzieło" [in:] J. Conrad, Jądro ciemności, transl. J. Polak, Poznań: Vesper, 2009, pp. 121-171.

Fordoński, K. "Polski przekład literacki w warunkach wolnego rynku. Spojrzenie nieobiektywne, prowokacyjne i stronnicze", Przektadaniec 2000, vol. 7, pp. 131-149.

Genette, G., Paratexts: Thresholds of Interpretation, transl. J. E. Lewin, Cambridge: Cambridge UP, 1997.

Harvey, K., “'Events' and 'Horizons': Reading Ideology in the 'Bindings' of Translations” [in:] Apropos of Ideology: Translation Studies on Ideology - Ideologies in Translation Studies, ed. M. Calzada Pérez, Manchester: St. Jerome, 2003, pp. 43-70.

Hermans, Th., "Introduction. Translation Studies and a New Paradigm" [in:] The Manipulation of Literature: Studies in Literary Translation, ed. T. Hermans, London \& Sydney: Croom Helm, 1985, pp. 7-38.

Heydel, M., "Trzymam gardę" [in:] Przejęzyczenie: rozmowy o przekładzie, ed. Z. Zaleska, Wołowiec: Wydawnictwo Czarne, 2015, pp. 271-300.

Jarniewicz, J., “...i inne głosy” [review], Literatura na Świecie 2012, no. 9-10, pp. 420-430.

Kimbrough, R., Conrad's Heart of Darkness: An Authoritative Text, Backgrounds and Sources Essays in Criticism, London \& New York: Norton \& Company, 1988, pp. 311-345.

Koc, B., "Biogram Katarzyna Batora" [in:] Wspótcześni polscy pisarze i badacze literatury: słownik biobibliograficzny, vol. 4, Warszawa: Wydawnictwa Szkolne i Pedagogiczne, 1996, p. 167.

--------, "Jądro ciemności w stulecie istnienia" [The Centenary of Heart of Darkness], Przeglad Humanistyczny 2000.

Lefevere, A., "Mother Courage's Cucumbers: Text, System and Refraction in a Theory of Literature" [in:] The Translation Studies Reader, ed. L. Venuti, New York: Routledge, 2012, pp. 203-219.

--------, Translation, Rewriting, and the Manipulation of Literary Fame, London \& New York: Routledge, 1992.

Listy Conrada do Rogera Casementa, comments by Z. Najder, transl. H. Carroll-Najder, Twórczość 1974, no. 8, pp. 31-35.

Lothe, J., Conrad's Narrative Method, Oxford \& New York: Clarendon Press, 1989.

Marzec, B., "Conrad o podróży do granic cywilizacji”, http://www.rp.pl/artykul/696923-Conrado-podrozy-do-granic-cywilizacji.html\#ap-1 (access: 4.08.2011).

----------, “Conrad o horrorze na wyspie Utøya”, http://archiwum.rp.pl/artykul/1067873.html (access: 8.09.2012).

Moc, A., "Nowe prawo autorskie a kolejne tłumaczenia na naszym rynku wydawniczym, czyli przygody Pinocchia albo Pinokia" [in:] Między oryginatem a przekładem, vol. 3: Czy zawód tlumacza jest w pogardzie?, eds. M. Filipowicz-Rudek, J. Konieczna-Twardzikowa, M. Stoch, Kraków: Universitas, 1997, pp. 181-189.

Koc, B., “Jądro ciemności w stulecie istnienia”, Przegląd Humanistyczny 2000, no. 1/2, pp. 107-114.

Lektor, Recenzja Jądra ciemności [Review of Heart of Darkness], Tygodnik Powszechny, 8.11.2011.

"Od wydawcy" [Publisher's Note] [in:] J. Conrad, Jądro ciemności, Warszawa: Ludowa Spółdzielnia Wydawnicza, 2000, pp. 5-8.

Polak, J., "Od tłumacza” [in:] J. Conrad, Jądro ciemności, transl. J. Polak, Poznań: Vesper, 2009, p. 171.

Simmons, A., Conrad's Heart of Darkness, London: Continuum, 2007, pp. 21-39.

Skibińska, E., Między oryginałem a przekładem, vol. 17: Parateksty przekładu, Kraków: Księgarnia Akademicka, 2011.

Skwara, M., Polskie serie recepcyjne wierszy Walta Whitmana, Kraków: Universitas, 2014. 
Sommer, P., "Czy ja robię refrakcję? O antologii Wspótczesne teorie przekładu” [dyskusja w redakcji „Literatury na Świecie”, P. Bukowski, M. Heydel, J. Jarniewicz et al.], Literatura na Świecie 2012, no. 3-4, pp. 351-377.

Szczurek, A., Recenzja, http://www.znak.com.pl/kartoteka,ksiazka,3075,Jadro-ciemnosci.

Tabakowska, E., "Słowo-po-słowie od tłumacza" [in:] L. Carroll, Alicja w Krainie Czarów, transl. E. Tabakowska, Kraków: Bona, 2012, pp. 115-116.

Venuti, L., Translation Changes Everything: Theory and Practice, London \& New York: Routledge, 2013.

---------, The Translator's Invisibility: A History of Translation ( $2^{\text {nd }}$ ed.), London \& New York: Routledge, 2008.

----------, The Translation Studies Reader, London \& New York: Routledge, 2012.

Watt, I., Conrad in the Nineteenth Century, Berkeley: University of California Press, 1981.

--------, "Impressionism and Symbolism in Heart of Darkness" [in:] R. Kimbrough, Conrad's Heart of Darkness: An Authoritative Text, Backgrounds and Sources Essays in Criticism, London \& New York: Norton \& Company, 1988, pp. 311-336.

, "Conrad's Heart of Darkness and the Critics" [in:] I. Watt, Essays on Conrad, Cambridge: Cambridge UP, 2000, pp. 85-96.

Watts, C., “'A Bloody Racist': About Achebe's View of Conrad”, The Yearbook of English Studies 1983, vol. 13: Colonial and Imperial Themes Special Number, pp. 196-209.

----------, “Conrad's Covert Plots and Transtextual Narratives", Critical Quarterly 1982, no. 24, pp. 53-64.

-------, "Heart of Darkness" [in:] The Cambridge Companion to J. Conrad, ed. J. H. Stape, Cambridge: CUP, 2004, pp. 45-62.

--------, "Introduction" [in:]: J. Conrad, Heart of Darkness and Other Tales, Oxford: Oxford UP, 1996, pp. vii-xxiv.

Wąsowicz, A.,"Pamiętaj,przekładwszystkozmienia",http://www.e-splot.pl/?pid=articles\&id=2723 (access: 2.09 .2014$)$.

Woolf, V., "Modern Fiction" [in:] Modernism and Literature, eds. M. Carter, A. W. Friedman, New York: Routledge, 2013.

Wróblewska, M., “'Tłumacze są niewidzialni'. Magdalena Heydel w 'Świętach z thumaczami””, https://xiegarnia.pl/artykuly/tlumacze-sa-niewidzialni-magdalena-heydel-w-swietach-z-tlumaczami/ (access: 26.11.2014).

Wyer, C., "Two Readings of Heart of Darkness", http://wayback.archive.org/web/20110302095028/ http://www.qub.ac.uk/schools/SchoolofEnglish/imperial/africa/Conrad-readings.htm (access: 1.01.2014).

Zabierowski, S., "In Memoriam Prof. dr hab Barbara Koc", Yearbook of Conrad Studies 2013, vol. VIII, pp. 155-157.

Zubrzycka, E., Recenzja [Review], http://www.znak.com.pl/kartoteka,ksiazka,3075,Jadro-ciemnosci. 